\title{
Extending Conservation to Farmlands in Zambia: Prescribed Practices and Reality
}

\author{
Orleans Mfune \\ ${ }^{1}$ Department of Geography and Environmental Studies, University of Zambia, Lusaka, Zambia \\ Correspondence: Orleans Mfune, Department of Geography and Environmental Studies, University of Zambia, \\ P.O Box 32379, Lusaka, Zambia. Tel: 260-211-290-03/260-969-171-456. E-mail: omfune@gmail.com
}

Received: October 31, 2013 Accepted: December 2, 2013 Online Published: December 27, 2013

doi:10.5539/jsd.v7n1p46

URL: http://dx.doi.org/10.5539/jsd.v7n1p46

\begin{abstract}
This article examines the extension of environmental conservation measures to agricultural landscapes in a developing country context. It is concerned with how, conservation agriculture, as an agri-environmental measure aimed at improving farmers' productivity while enhancing ecosystem services on farmland, is framed, translated into practice, adopted by smallholder farmers and how its practices fit with the livelihood realities of the farming households. Further, the paper is concerned with local level factors that limit the application of such measures in agricultural landscapes in Zambia. The data on which this paper is based was collected through a questionnaire survey, interviews, focus group discussions and farm site visits in Chongwe District of Central Zambia. The results of the study show that conservation agriculture in Zambia is framed in such a way that it is limited to a set of practices prescribed by some of the leading organisations involved in its deployment and ignores some local practices with potential to contribute to its objectives. Moreover, some of the prescribed conservation agricultural measures are not in harmony with the organisation of local livelihoods, negatively impact on household human capital (i.e. family labour demand), and ignore the bio-physical conditions of the areas where they are being promoted.
\end{abstract}

Keywords: agriculture, land, agri-environment, conservation, ecosystem services, livelihoods, farming households

\section{Introduction}

For decades, conservation in Africa has been confined to environments specifically designated as 'protected areas'. This type of conservation has often been guided by narrow conservation goals primarily focused on protection of wild species and lands seen as 'pristine' environments (Primark, 1993; Scherer \& McNeely, 2008). More recently, however, it has been argued that conservation should broaden its goals to include a focus on the enhancement and maintenance of a broad range of ecosystem services (such as biodiversity conservation, air and water purification, and carbon sequestration and climate regulation) and enhancement of rural livelihoods. In this regard, over the past two decades, the question that both academics and conservation practitioners have been grappling with is: how, and in what other type of environments, can both rural livelihoods and ecosystem services be enhanced and maintained? In response to this, some scholars such as Scherer and McNeely (2008) have argued for an extended thinking about environmental conservation that goes beyond protected areas to encompass socio-ecological systems, in order to conserve and sustain ecosystem services and enhance livelihoods (see also Batary et al., 2011; Ferraro \& Simpson, 2005; Kareiva et al., 2007; Reeves, 2011; Vaccarro \& Beltran, 2001; Vandarmeer \& Perfecto, 2005; Zwaan, 2010). They argue that conservation should shift from simply preserving natural areas to shaping the ecological processes in human domesticated lands in order to enhance human wellbeing (Karieva et al., 2007; Fish et al., 2003). Agricultural environments, in particular, have emerged as the most important focus of this new conservation debate. Batary et al. (2011), for example, draw attention to the fact that "more than half of the earth's surface is molded by agriculture, so the contribution of agriculture is critical for successful long-term conservation" (see also Amdur et al., 2011). Moreover, agriculture is one of the most important land-land uses that affect the quality of rural environments (Cunder, 2007). Consequently, it is argued that combining conservation in protected areas such as forest reserves with that on farmland is a well-balanced way of doing conservation (Batary et al., 2011). 
This undertaking of conservation measures on farmland is what is often referred to as 'agri-environmental management' (AEM). Agri-environmental management is a land management strategy that posits a win-win scenario for both environmental conservation and livelihoods. Globally, the adoption of AEM policies is quickly gaining ground. In developed countries, such as those in the European region, AEM strategies are supported by payments for agri-environmental services schemes that allow farmers to receive payments for undertaking AEM measures on farmland. In this regard, the bulk of scholarly work on AEM has mainly concentrated on AEM schemes being implemented in Europe and other developed regions. On the other hand, in other regions such as Africa, a lot still remains to be learnt about the type of AEM measures being adopted and deployed to farming environments. This paper seeks to contribute to the documentation of African countries' experiences with implementation of AEM strategies. Using conservation agriculture, as an example, it is concerned with how such strategies are framed, applied to specific local environments and how they sit with local level realities.

\section{Agri-Environmental Management and Conservation Agriculture}

There are various types of measures that can be adopted in agri-environmental management systems. However, one element defines them: that is that they have at least two objectives, reducing environmental risks associated with modern agriculture and preserving nature or delivering a range of ecosystem services, while at the same time improving the livelihoods of farmers (Cunders, 2007; Dumanski, 2006; EU, 2005; Gorman et al., 2001; Kleijn \& Sutherland, 2003; Scherr \& McNeely, 2008). Table 1 presents some of the agri-environmental measures that are being adopted in conservation and agricultural policies across the world.

Table 1. Type of agri-environmental management measures

\begin{tabular}{lll}
\hline Categories of & Agri-environmental & Detailed description of measures \\
agri-environmental & approach & \\
\hline
\end{tabular}
measures

\begin{tabular}{ll}
\hline Measures on cropland $\quad$ Conservation agriculture & $\begin{array}{l}\text { Low impact agriculture, minimum tillage, reduced } \\
\text { inputs, planting of multi-purpose trees and shrubs, }\end{array}$
\end{tabular}
crop-rotation, improved fallow systems

Agro-forestry

Organic agriculture

On pasturelands Silvi-pastoral systems

Has positive impact on soil fertility, water conservation, biodiversity and carbon storage

Takes various forms - trees and shrubs on home gardens, dry-land farms etc.

Has positive effect on water catchments, soil fertility, carbon sequestration, biodiversity.

Low impact agriculture involving no inputs, crop rotation.

Has positive impact on soils, biodiversity and water systems

Planting high density of trees and shrubs in pastures to provide diet and shed supplements and prevent erosion

Using fast-growing trees for fencing rangelands

They are considered to have positive effects on water, biodiversity, carbon sequestration and watershed protection

Non-productive-land measures
Set-asides, preservation of care of woods, hedges, conversion of arable land to grasslands
Non -productive land measures for the preservation of the rural environments and enhancement of biodiversity.

Also provide water-shed protection, carbon-sequestration, soil protection, pollination services and aesthetic services

Source: World Bank, 2008; Baudron et al., 2007; Borsotto et al., 2008; EU, 2005; Dumanski et al., 2006; EU, 2005; Goman et al., 2001.

This shift towards agri-environmental management implies that agriculture areas must be viewed as multi-functional landscapes which do not only produce food and fibres, but also various ecosystem services being demanded by society (Gorman et al., 2001; Melania \& Sayid, 2011; Milestad et al., 2011; Pretty et al., 2003). The idea of extending conservation to agricultural landscapes heralds a new era of environmental 
conservationism and should be seen as a radical shift from the protected area thinking which viewed agro-landscapes as 'biological deserts' or a 'hostile matrix of isolated habitat fragments' (Batary et al., 2011: 1894). In this wave of conservationism, agricultural environments and related landscapes are seen to be worthy of conservation because they assert, rather than deny, the value of socially induced change on the environment (see Fisher et al., 2003; Scherr \& McNeely, 2008; Baker \& Stockdale, 2008).

As already noted, a variety of measures can fit into the notion of agri-environmental management. This paper, however, focuses explicitly on one agri-environmental strategy - conservation agriculture (CA). This is one of the agri-environmental measures that are aimed at reducing environmental risks (i.e. through minimum tillage, reduced farming inputs and agro-forestry practices), while at the same time improving the productivity of farm plots (Altieri \& Nicholls, 2005; Dumanski et al., 2006; Pretty et al., 2003; Prosperi et al., 2011; WAC, 2010). Conservation agriculture has been defined differently by different authors. However, a generic definition provided by the FAO presents $\mathrm{CA}$ as a concept for resource-saving agriculture that strives to achieve high and sustained agricultural production, while concurrently conserving the environment (Boudron et al., 2007; FAO, 2009). It is based on enhancing natural biological processes above and below the ground, and involves interventions such as reductions in mechanical soil tillage and the application of external inputs (such as agrochemicals), in such a way that does not interfere with, or disrupt the biological processes in this system (see Dumanski et al., 2006). This definition explicitly ties CA to agricultural production and environmental conservation, merging the two, in line with the sustainable development discourse.

Conservation agriculture is common in parts of South America and the USA (WAC, 2010) but is now being deployed to other parts of the world such as Africa (Baudron et al., 2007; WAC, 2010). By 2010, only 1\% of Africa's agricultural land was under conservation agriculture and other agri-environmental initiatives (WAC, 2010). This shows that CA in Africa is still in its infancy. Zambia is among the countries viewed as the pioneers of $\mathrm{CA}$ on the continent. Conservation agriculture has found expression in Zambia's agricultural and environmental policies (GRZ, 1998; 2007). The National Environmental Policy (NEP), for example, seeks to promote the integration of trees and shrubs into farming systems, adoption of soil conservation activities and other sustainable land-use systems. It is hoped that such new forms of land management will promote the rehabilitation of marginal land, improve farmers' livelihoods, deliver a range of ecosystem goods and services (such as wood energy, carbon storage and carbon sequestration) and promote farmers' environmental stewardship. At the time of this study's fieldwork, the Conservation Farming Unit noted that over 160, 000 farmers were practicing CA in Zambia (personal communication).

With CA ideas now being deployed to rural environments in Zambia, some scholarly works have begun to emerge, generating early lessons on the implementation of conservation agriculture, with some studies focusing on the gender dimensions of CA adoption by farmers (Nyanga, 2012) and CA's effects on soil biophysical properties (Umar, 2012). It is important, however, to note, that such CA practices are not taking place in a vacuum, but are taking place in contexts where farmers have their own way of organizing their livelihoods. Prescribed CA measures can only be successfully implemented if they fit with the livelihood realities of the people. In this regard, as a point of departure from other studies, this paper provides an appreciation of how CA is framed in Zambia, the implications of this framing and how it sits with local level livelihood realities. Further, it answers the question of what factors condition the application of CA practices among farming households in Zambia. The lessons generated from Zambia's experience with CA are crucial, not just for the implementation of CA in Zambia, but also for its deployment to other parts of the continent.

\section{Approach and Methods}

The analysis of conservation agriculture in this paper draws on insights from the sustainable livelihood perspective which emphasizes the importance of understanding how rural actors organize their livelihoods and the factors that condition the achievement of sustainable livelihoods. A livelihood perspective shows how, in their pursuit of a combination of livelihood strategies, rural actors draw on a range of livelihood resources (natural, economic, social, physical and human) to construct 'sustainable livelihoods' (Chambers \& Conway, 2012; Ellis, 2000; Rigg, 2007; Scoones, 1998). The notion of 'sustainable livelihoods' has two important components that are particularly important for this paper. These are 'improvement in the well being of the people' and 'ensuring the sustainability of the natural resource base' (i.e. maintaining the integrity of the environment). Interventions such as conservation agriculture are meant to improve the wellbeing of rural actors (through increase in their access to livelihood resources) and to maintain the sustainability of the rural asset base through the undertaking of conservation measures on farmland. However, to be successful, such interventions need to be in harmony with the way rural actors organize their livelihoods. 
An understanding of the way in which people construct their livelihoods is crucial as many policy framings and project interventions are based on poor understandings of people's livelihoods (Bebbington, 1999). In many cases, interventions aimed at solving rural problems are framed in such a way that they promote activities that are not consistent with the basic organising principles of local people's livelihoods (Benjamin, 2004). In this regard, it is critical, in a study such as this, to first analyze the way such interventions are framed and the implications of such framings for local livelihoods. Further, at the heart of the livelihood framework is an analysis of the role of institutional factors in mediating access to livelihood resources. Institutions, which are viewed here as rules-in-use are critical to the organization of local livelihoods and often determine what local actors can do and cannot do. Without paying attention to institutional arrangements at sites of implementation, interventions such as CA have little chance of success. By drawing on these insights from a livelihood perspective, this article focuses its attention on how $\mathrm{CA}$ is framed and its implications for the local environment and livelihoods and the fit between prescribed CA practices and local livelihood practices and realities. Further, the article focuses its attention on how institutional and other local level factors influence the application or adoption of CA.

The paper draws on 11 months of field research conducted in Chongwe District of Central Zambia. Chongwe district was selected as a study area primarily because it's one of the districts where conservation agencies and the government are implementing conservation agriculture initiatives. In the first stage of the fieldwork, interviews and focus group discussions were conducted with both farming households (located at sites where CA initiatives are being promoted) and representatives of organizations promoting CA or with an interest in CA in Chongwe. In total, interviews were held with 94 adult individuals from four farming villages of Chongwe in order to assess their experience with conservation agriculture. The individuals targeted for the study were mainly household heads (male or female). The interviews provided data on local level realities and farmers' views on the practice of conservation agriculture and other natural resources related issues. Alongside interviews with farming households, 34 interviews were conducted with organizations associated with CA and natural resources conservation in Chongwe. Research participants included conservation practitioners from the government and NGOs, local government officials, environmental policy makers and agricultural officers. While some of these actors do not reside in Chongwe and operate at various levels (national, district and local level), they were selected to participate in the research on the basis that they were either involved in the promotion of CA in the area or had an influence on its implementation. In total, 34 interviews with these research participants were conducted.

Further, to complement these qualitative methods and provide an opportunity for triangulation of results, a questionnaire was administered to 120 households (again targeting the heads of households) in the study area primarily aimed at collecting data on livelihood strategies and resources. Simple random sampling where numerical codes were attached to all the households and then selected through a table of random numbers was employed to select the households to participate in the survey. A sample of $25 \%$ of all households in the study area was assumed to be sufficient for the study. The total number of households in the study villages was 390 . In the final stages of the study, 100 on-site farm visits were also carried out for the purpose of observing the type of agricultural practices that farmers were engaged in. Of the 100 farm plots visited, 60 farm plots were under conservation agriculture, while 40 were under conventional farming methods. A survey sheet that more or less acted as a checklist was used to record on-farm practices in the two study sites. This list was generated from interview data and prior field visits and checked as 'observed' or 'not observed'. The results obtained provided an empirical basis for comparing what farmers do in practice with CA prescriptions from organisations working in the study sites. They also provided a basis for analysing the distribution of on-farm practices among research participants.

\section{Results and Discussion}

\subsection{The Local Livelihood Context}

Households in the study area rely on a variety of strategies to construct their livelihoods. These strategies include crop farming, livestock rearing, and small-scale trading and wage employment. Despite these diverse strategies, the results of the household survey show that crop farming and livestock rearing are the two most important livelihood strategies in the study villages. Over $96 \%$ are involved in crop production and identify themselves as farmers. Further, over $50 \%$ of the households are engaged in livestock rearing. Due to the importance of these two livelihood strategies, land for agriculture and grazing are considered among the most important livelihood assets of the people in the study area. On agricultural land, households mainly cultivate maize (which is the staple food in the country), groundnuts, beans and sweet potatoes. While livestock rearing relies on surrounding communal woodlands and bush lands for grazing, in the dry season, when grazing resources are scarce and 
farmers have harvested from their fields, the crop fields are also released for livestock foraging. This arrangement is permitted by land tenure arrangements that allow livestock farmers to have access to crop fields during the dry season. Access to land and other natural resources in the study area is predominantly governed by customary institutional arrangements. Nearly all farmers in the study area rely on customary land for cultivation, livestock grazing and other livelihood practices.

Given the place of crop farming in people's livelihoods, CA was introduced on farmland only and excludes grazing lands. There are a range of actors involved in CA related activities in the study site. While the activities are mainly funded by the Norwegian government, the EU and some Australian Christian organizations, at the site level, conservation agriculture initiatives are being implemented by the Ministry of Agriculture, the Conservation Farming Unit (CFU) and Christian Child Fund Zambia. According to one of the senior agricultural officers, conservation agriculture has been on pilot state in this district for more than six years now, and in the past two years, the participating partners have moved to introduce it in all parts of the district. Chongwe is only one of the 12 districts where conservation agriculture is being implemented on a full scale in all communities. The involvement of such a diverse range of actors in the deployment of conservation agriculture shows the high interest that agri-environmental approaches are generating among development practitioners and conservation agencies alike. The main reasons given by these actors for their participation in CA initiatives are summarized in Table 2.

Table 2. Reasons given by various actors for their involvement in CA

\begin{tabular}{ll}
\hline Actor Involved & Reasons for Involvement \\
\hline The Food Agriculture Organization & $\begin{array}{l}\text { Promotion of farmer productivity, farmer resilience to } \\
\text { climate change }\end{array}$ \\
(LA) & $\begin{array}{l}\text { Promote farmer environmental stewardship } \\
\text { CA's capacity to address deforestation and restore } \\
\text { degraded lands. }\end{array}$ \\
Conservation Farming Unit (CFU) & $\begin{array}{l}\text { Increase farmer productivity, Soil conservation, } \\
\text { adaptation to climate change and tree conservation }\end{array}$ \\
Christian Child Fund Zambia (CCF) & $\begin{array}{l}\text { To increase the livelihood assets of rural households } \\
\text { GRZ (department of agriculture) }\end{array}$ \\
Interest in food security and agricultural growth, \\
resources for extension services, funding for agricultural \\
development \\
Avoided deforestation \\
Ministry of Environment (FD) \\
Restoration of degraded lands \\
Biodiversity conservation, ecosystem services protection \\
Poverty reduction through increased farmer productivity \\
and food security \\
Helping country achieve MDGs \\
Sustainable development commitments \\
Adaptation to climate change
\end{tabular}

Source: Field data (interviews with organisations participating in CA).

The results presented in Table 2 suggest that the popularity of CA lies in its capacity to address the diverse interests of the various actors involved. Apart from the conservationist interests, CA also appeals to the interests of agriculturalists in terms of addressing household food security and climate change adaptation. According to the senior agricultural officer who participated in this research, there are three main issues of concern for the agriculture department. These are declining yields due to poor soils, unpredictable rainfall patterns linked to climate variability and change, and farmers' declining access to farming assets such as fertilizer, seeds and farm implements. Conservation agriculture, with its emphasis on nutrient restoration and soil improvement, water conservation and low levels of agriculture inputs, is viewed as one of the tools for resolving these challenges. 


\subsection{How CA Is Framed and Practices Prescribed for Local Farmers}

Although in the introductory section, this paper has provided a definition of what may be termed as conservation agriculture in broad terms (i.e. from reviewed literature), CA can, in fact, be framed and done in a variety of ways depending on the context (see also Boudron et al.). With such a broad range of actors involved in CA in Zambia, it is important to understand what is being framed as CA in the context of the case under consideration in this paper. This provides us an understanding of what exactly is being prescribed to farmers and deployed to farm sites and its implications on the local environment and people's livelihoods. According to the Ministry of Agriculture, in the context of Zambia, the trend is to follow the Conservation Farming Unit's (CFU) definition of what constitutes conservation agriculture. The CFU is viewed as the pioneer of CA in Zambia, having started piloting it 10 years ago. The CFU is also linked to a research unit called Golden Valley Agricultural Research Trust (GART). Together, the CFU and the GART have become the leading source of knowledge and best practice about CA. The CFU defines conservation agriculture as having two components; 'conservation farming' and 'establishment of trees' on agricultural lands (Box 1).

Box 1. Conservation agriculture as envisioned by CFU

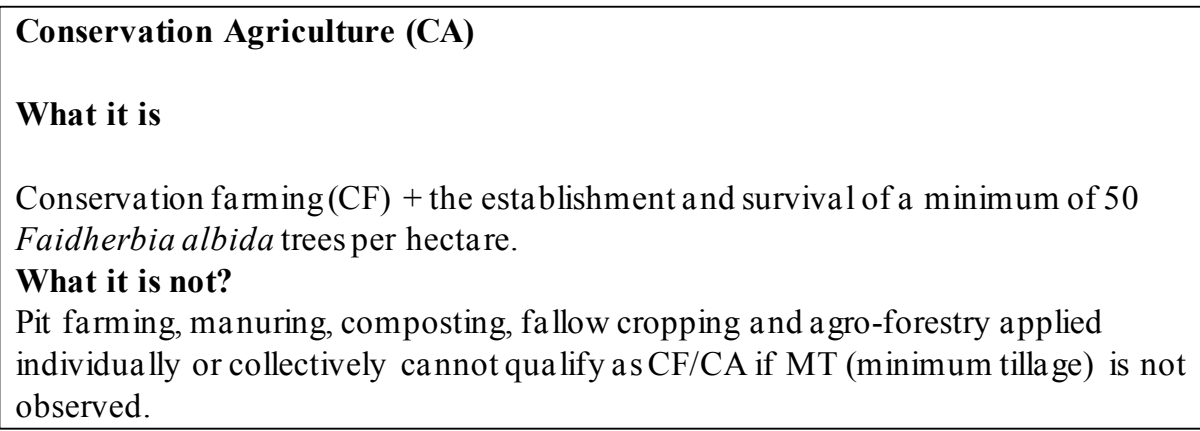

Conservation farming (CF), as the first component of conservation agriculture, refers to a package of farming practices which includes the application of conservation tillage (minimum or zero tillage) through the creation of permanent crop planting basins, use of leguminous crops, crop rotation and retention of crop residues on the farm (Table 3).The use of minimum tillage is said to improve the soil's biophysical properties and reduce soil disturbance to around 12\% percent of the field (WAC, 2010; Dumanski, 2006). It increases soil productivity and avoids further environmental damage from the use of inversion tillage systems which threaten water quality, erode soil and reduce soil biodiversity (FAO, 2009).

Conservation tillage is practiced in two ways. In the first method, farmers create small permanent planting basins with hand hoes and plant seeds in these holes each year (Table 3). This is the only method utilized by CA farmers who participated in this research. The second method involves the use of ox-drawn or tractor drawn rippers to create thin trenches into which the seeds are sown (see also WAC, 2010). Although ripping technology is now available in the country, more than $90 \%$ of the research participants expressed ignorance about its availability (perhaps an indication that local actors lack information on new developments in conservation agriculture). 
Table 3. Differences between CA and conventional farming in the study area

\begin{tabular}{|c|c|c|}
\hline $\begin{array}{l}\text { Agricultural } \\
\text { practices }\end{array}$ & Conventional farming & Conservation agriculture \\
\hline $\begin{array}{l}\text { Land } \\
\text { preparation }\end{array}$ & $\begin{array}{l}\text { Field often ploughed by tractor or } \\
\text { ox-drawn or tillage practiced by hand } \\
\text { hoes - for example } 60 \% \text { use } \\
\text { ploughs, including adopters on land } \\
\text { which is not under CA }\end{array}$ & $\begin{array}{l}\text { Minimum tillage emphasized, farmers use hand hoes } \\
\text { to create permanent planting basins. This can also be } \\
\text { practiced by using ox-drawn rippers to create rip } \\
\text {-lines } \\
\text { In the study, however, none of the research } \\
\text { participants had access to ripper; the price of a ripper } \\
\text { is about US\$ } 200 \text {. }\end{array}$ \\
\hline $\begin{array}{l}\text { Use of crop } \\
\text { residues }\end{array}$ & $\begin{array}{l}\text { Crop residues burnt in some places in } \\
\text { Zambia } \\
\text { However, in both study sites, crop } \\
\text { residues left for livestock foraging }\end{array}$ & $\begin{array}{l}\text { Crop-residues viewed as part of organic cover - } \\
\text { however, farmers note that there are a lot of } \\
\text { problems in permanently retaining crop residues in } \\
\text { the farm sites due to conflicts with livestock }\end{array}$ \\
\hline $\begin{array}{l}\text { Rotation and } \\
\text { diversification } \\
\text { of cropping } \\
\text { systems }\end{array}$ & $\begin{array}{l}\text { Mono-cropping often emphasized in } \\
\text { conventional agriculture previously } \\
\text { promoted by the state, but study } \\
\text { shows that mixed cropping is the } \\
\text { norm among small scale farmers in } \\
\text { the study area }\end{array}$ & $\begin{array}{l}\text { Crop rotation of maize with leguminous plants } \\
\text { emphasized. Leguminous plants improve the nutrient } \\
\text { content of the soil. } \\
\text { Also improved fallow with green manure such as sun } \\
\text { hemp and cow- peas emphasized in CA- study only } \\
\text { found } 3 \% \text { have used green manure before. }\end{array}$ \\
\hline $\begin{array}{l}\text { Integration of } \\
\text { trees }\end{array}$ & $\begin{array}{l}\text { Emphasis on agricultural } \\
\text { mechanisation promoted removal of } \\
\text { wild tree species. } \\
\text { However, in the study areas study } \\
\text { found that } 70 \% \text { of farmers still retain } \\
\text { trees on farm sites. }\end{array}$ & Emphasis on intercropping maize with Msangu tree \\
\hline $\begin{array}{l}\text { Application } \\
\text { of Fertilizers, } \\
\text { Herbicides } \\
\text { and Pesticides }\end{array}$ & $\begin{array}{l}\text { Conventional agriculture is overly } \\
\text { focused on use of fertilizers. }\end{array}$ & $\begin{array}{l}\text { Minimum emphasis on fertilizers and pesticides } \\
\text { although not entirely excluded as in organic farming. } \\
\text { Emphasis on use of leguminous plants instead (at } \\
\text { least } 30 \% \text { of field should have leguminous plants) - } \\
\text { this is good as it may emphasize plants grown by } \\
\text { women). }\end{array}$ \\
\hline
\end{tabular}

Source: Field Data.

The use of minimum tillage, as seen in Table 3, is perhaps one of the major elements that distinguish conservation agriculture from conventional agriculture in the study area. The emphasis on minimum tillage and minimum farm inputs is a major departure from agricultural modernization policies adopted at Zambia's independence which emphasized the mechanization of the agricultural sector and the extensive use of fertilizers and pesticides. Similarly, a respondent from the CFU office notes that CA in Zambia should be viewed as a reform process in agriculture, from policies that promoted the mechanization of agriculture, agriculture mono-cultures and extensive application of fertilizers and pesticides to a new approach that emphasizes agriculture diversification, environmental care and reduced farming inputs. This is also reiterated by Dumanski et al. (2006), who note that CA is not a business-as-usual scenario, based on maximizing yields while exploiting the soil and agro-ecosystem resources; rather, it is based on optimizing yields and profits to achieve a balance of agriculture, economic and environmental benefits. Conservation agriculture, in this regard, represents a new paradigm in agriculture, one which the World Agro-Forestry Center hails as creating an evergreen agriculture for food security and environmental resilience (WAC, 2010).

In CFU's framing of CA, the environmental benefits of conservation agriculture are supposed to be reinforced by the second major component of CA (Box 1 and Table 3), which is the planting of multipurpose trees to be intercropped with cultivated crops. The integration of trees in farming systems, in addition to the use of planting basins and the emphasis on diversification of cropping systems is suppose to increases the resilience of the 
farming systems to climatic stresses, such as dry spells, shortened rain season, floods and pest attacks prominent in the area. Further, it is suppose to increase farmers access to diverse livelihood assets (firewood wood, livestock feed, soil fertility, increased crop production), and at the same time deliver important ecosystem services (biodiversity conservation, carbon storage, water conservation, reduced erosion, reduced pollution of aquatic and forestry ecosystems from pesticides and fertilizers). This makes CA a vital ally of mainstream conservation strategies as well as a tool for construction of sustainable livelihoods. However, CA as framed here, limits tree growing on the farm sites to specific tree species called the Msangu (Falderbia albida). The Msangu tree is a native of Africa that belongs to the Acacia tree species. The choice of the Msangu is based on scientific findings that the tree has special properties that make it a valuable non-food plant to integrate in farming systems (see also Dupuy \& Dreyfus, 1992 on the properties of Acacia albida). This tree is leguminous and fixes nitrogen in the soil and therefore can be important for soil fertility improvement. Further, it has been argued that maize grown under a Msangu tree canopy can reach up to 3 tonnes per hectare as compared to 500kg per hectare away from the tree's canopy (Simuji et al., 2008a). Moreover, the tree does not compete with crops for light as it sheds its leaves in the cropping season and lets them grow in the dry season. This process, which makes it compatible with crop growing, is called reverse leaf phenology (GRZ, 1998). The leaves, when shed, also provide nutrients for the soil and organic cover (together with crop residues) to protect it against erosion. Apart from its ecological benefits, the Msangu tree provides good timber, firewood; charcoal and its pods and leaves are also used as protein-rich livestock folder. It is the inclusion of such elements in agricultural landscapes that make conservation agriculture fit into the idea of multi-functional agricultural systems which deliver multiple benefits to households and society as a whole.

From what is framed as CA here, it is evident that the outcomes of conservation agriculture, as perceived by its proponents, in the context of Chongwe, are sustainable livelihoods and the sustainability of the resource base, showing a win-win situation. However, the way CA is presented here is not just important for what it includes, but it is also important for what it excludes. In Table 2, CA is limited to a set of practices prescribed by CFU as the leading actor in the deployment of conservation agriculture and ignores a range of other agro-forestry practices, some of which are already being practiced by local actors. During on-farm visits in the study sites, it was observed that farmers retain wild plant species on farm sites as wind breaks, farm boundaries, fruit trees and medicinal plants. As indicated in Table 3, this was the case with at least $70 \%$ of the farm plots visited in the study area. While the pre-occupation with the Msangu is understandable (in view of its special properties discussed in the preceding section), there is a danger that this over-emphasis on one tree species may serve to de-emphasise the importance of those tree species which already play an important role in farmer's livelihoods. These local agro-forestry practices have potential to contribute to the goals of enhancing ecosystem services and improving the quality of agricultural environments. This framing of CA also demonstrates the lack of local farmers' involvement in defining the key elements of CA. Allowing local farmers to be involved in such a process would provide an opportunity to identify the best options for CA taking into consideration farmers' experiences and knowledge of the local livelihood context.

\subsection{What Farmers Actually Practice on Their Plots}

While the preceding section has set out the CA practices prescribed for farmers' adoption, farm visits carried out in this study show a lot of discrepancies between what is prescribed and what is adopted by farmers. The actual farm practices observed on the farms visited are presented in Table 4. In total, there were 60 farms using CA, representing $60 \%$ of the farm plots visited. From the table, the results in practices of CA farmers can be compared with the practices of farm sites not on CA. 
Table 4. Farm practices on both CA and non-CA farm plots

$\begin{array}{lcc}\text { CA activities on farm site } & \begin{array}{c}\text { Percentage of farm sites where activity was carried out } \\ \text { CA adopters } \\ \text { (N=60) }\end{array} & \begin{array}{c}\text { CA adopters } \\ \mathbf{( N = 4 0 )}\end{array} \\ \begin{array}{l}\text { Creation of planting basins (minimum tillage) on } \\ \text { farm portions }\end{array} & 100 \% & 0 \% \\ \text { Crop residues left on the farm immediately after } & 100 \% & 100 \% \\ \text { harvest } & & \\ \text { Mixed cropping practiced on farm } & 88.3 \% & 80 \% \\ \text { Crop rotation (maize/legume) } & 76.7 \% & 67.5 \% \\ \text { Intercropping of food crops } & 41.7 \% & 35 \% \\ \text { Farm plot where the Msangu was attempted } & 11.7 \% & 0 \% \\ \text { Minimum tillage done on whole farm } & 3.3 \% & 0 \% \\ \text { Green manure use and improved fallow systems } & 3.3 \% & 0 \% \\ \text { Other shrubs were planted as part of CA } & 0 \% & 0 \% \\ \text { All crop residues permanently retained on farm } & 0 \% & 0 \% \\ \text { (all year) } & & 0 \% \\ \text { Farm plots with Msangu tree standing } & 0 \% & 0 \% \\ \text { Use of mulch } & 0 \% & \end{array}$

From Table 4 it can be observed that crop rotation, mixed cropping and the retention of crop residues are widely practiced by both CA adopters and non-adopters. This stems from the fact that these activities were already common practices in the area, even before the introduction of CA. An important contribution of CA here is the fact that it has served to reinforce these practices. On the other hand, the retention of crop residues on the farm plots has to be viewed with caution. While crop residues are indeed retained on all the fields after harvest, they are hardly ever permanently retained as the fields are traditionally released for livestock dry season foraging.

A notable practice that sets CA farm plots apart from those where conventional farming is practiced is the use of minimum tillage in land preparation. All CA adopters practice minimum tillage, primarily because this is often the indicator used by the extension officers to identify who has signed up for CA. This also suggest that statistics indicating that over 160, 000 small holders, representing $10 \%$ of small scale farming households in the country have adopted CA need to be treated with caution, as they do not reflect what other practices have been adopted by farmers apart from minimum tillage.

However, although the results in Table 4 indicate that minimum tillage was being practiced on all the 60 farm plots that were under conservation agriculture, only two (representing $3.3 \%$ of adopters) had placed their whole fields on conservation tillage. On the rest of the farms, conservation tillage is practiced side by side with conventional tillage farming. Adopters of CA interviewed in this study identified two main reasons why they opted to reserve only small portions of land for CA. First, more than half of all CA adopters noted that conservation tillage is time-consuming and places a lot of demand on family labour requirements. In particular, they argue that simply creating planting basins rather than tilling the land before planting allows weeds to grow quickly and to compete with cultivated crops. In contrast, under conventional agriculture, the land preparation process involving tillage ensures that weeds in the field are cleared with hand hoes or ploughs before planting. Weed clearing, according to these farmers, is one of the most time-consuming and laborious tasks in which they have to engage. According to one of the leaders of the women's group in the area, at the household level, this type of work is often left to women and children. Consequently, this creates an extra burden on women already overstretched with other household tasks. The weeding problem was also mentioned by at least a third of non-adopters as the main reason why they shied away from CA.

Apart from labour-related problems, at least a third noted that they had spared only small portions of their land for conservation agriculture, because they were only trying this approach to farming for the first time (or in some cases second time). It was observed that at least $25(41.7 \%)$ of the farmers on CA were new adopters (i.e. it was 
their first year on CA). In this regard, these small portions were experimental plots for these farmers, which suggest that farmers no longer unquestioningly adopt agricultural technology without first putting it to a test. This may stem from the fact that farmers have been subjected to a range of agricultural experiments over the past four decades, sometimes with disastrous outcomes. Besides this group, the study finds that some of the farmers devoted portions of their land to conservation tillage simply because they were attracted to subsidized fertilizer and seed packs that came with the adoption of conservation tillage. Although this is a view that was not openly expressed by most research participants, at least two farmers were open enough to point out that the fertilizer pack was an opportunity that they could simply not let pass.

Overall, the results show that there is a very low adoption of most of the key elements of CA. From Table 4, practices least adopted include (a) integration of tree species on farm plots (only 11.7\% attempted to do so); (b) use of green manure and improved fallow systems (3.3\%); (c) permanent retention of all crop residues ( $0 \%)$; and (d) use of mulching ( $0 \%)$. According to a research participant from the Conservation Farming Unit, these are crucial elements of conservation agriculture, as they delineate CA from other agricultural approaches. For example, he notes that "the absence of trees or shrubs on farm sites where CA is said to be practiced means what we cannot in a strict sense say that these farmers are practicing conservation agriculture". The retention of crop residues, improved fallow systems and mulch are all meant to create a permanent organic cover on agricultural lands. Together with the tree components, it is these elements that enhance the capacity of agricultural lands to produce ecosystem services.

\subsection{Factors Influencing Adoption of Conservation Agriculture Practices}

The huge gap between what is prescribed and what is practiced raises numerous questions about the process of translating conservation agriculture into practice. For example, it raises the question of the extent to which CA contributes to enhancing ecosystem services and increasing local actors' access to non-agricultural livelihood assets (e.g. firewood, construction poles and other products). At the moment, CA has not delivered on these promises. In particular, the ecological components of CA are the most neglected in the process, with CA farmers failing to integrate the prescribed trees and shrubs on the farm plots. Indeed, the study finds that there are several factors that hinder farmers' adoption of some of the CA practices, as well as limit CA's contribution to local livelihoods and environmental protection. The first factor, the issue of labour, has already been discussed in the preceding section. An important point to note here is that these new practices, such as mulching, use of improved fallow systems and planting of trees, all place an extra demand on family labour requirements. Apart from the labour problem, other factors that present challenges for CA implementation include: (a) a mismatch between prescribed CA practices and the organization of local actor's livelihoods system; (b) institutional constraints that mediate local livelihood practices and (c) biophysical conditions.

\subsubsection{Mismatch Between CA Practices and Organization of Local Actor's Livelihood Practices}

For conservation agriculture initiatives to succeed, it is important to align them to the local context within which they are being implemented. However, in the case of Chongwe, it was observed that some prescribed CA practices ignore the organisation of local actors' livelihoods system and the influence of seasonality on this organization. For example, focus group discussions held with the community show that the emphasis on permanent retention of crop residues and the establishing of the Msangu present a challenge for the community, because of the way their livelihood system is organized. The research participants noted that crop residues are not burnt after harvest, but are retained in the fields as livestock feed during the dry season when pasture is in short supply. This situation reflects a scenario where there is interdependence between crop-based livelihood systems and livestock-based livelihoods in order to cope with seasonal changes in the availability of resources. The farmers note that it is a daunting task to protect Msangu seedlings from cattle during the periods when fields are released by individual farming households for communal grazing. An effective implementation of these practices require that farmers exclude livestock foraging in their fields, a practice that may have negative implications on livestock-based livelihoods which form an important part of local actors' diversified livelihood strategies.

\subsubsection{Institutional Factors That Mediate Access to Livelihood Resources}

Interviews held with local elders in the study area show that excluding livestock from farming environments also has an implication for the local actors' institutional arrangements which mediate access to resources such as land and grazing sites. For example, one of the local elders notes that:

“...to say that we keep away livestock from our farms is going against custom, if we have harvested our crop, others have the right to allow their cattle feed from the fields... we cannot fence our fields just like that,....and you have to realize that in the dry season, it's difficult to find food for animals..." 
This view was also echoed by more than a third of the farmers involved in CA, who also noted the difficulty of going against local customs by excluding other actors (e.g. farmers without livestock excluding livestock keepers) from their fields during the dry season. Indeed, farmers seem to view this process of restricting access to their farm plots during the dry season as promoting the individualization of landholding, and thus tampering with local institutional arrangements which are characterized by flexibility to fit the local circumstances discussed in the preceding section. These local institutional arrangements enable local actors to organize their livelihoods and deal with seasonal resource changes in their environment.

\subsubsection{Environmental or Biophysical Factors That Constrain Local Livelihoods}

Apart from the importance of the institutional factors described above, the study found that CA adopters also have to contend with biophysical factors that constrain the implementation of some of the CA practices. For example, the seven farmers (representing $11.7 \%$ of all CA adopters in Table 4) who attempted to grow Msangu on their fields also cited biophysical constraints as one of reasons their tree planting efforts failed to yield positive results. Three of the farmers noted that the seedlings were destroyed by termites, while two of them indicated that their on-farm water holes used to irrigate the seedlings dried up in the dry season. Faced with the task of walking long distances to collect water from streams for irrigation, they simply gave up on the tree seedlings. Indeed, one of the agricultural extension officers pointed out that despite the push for farmers to grow the Msangu, the challenge of termites in Chongwe is a key problem. The importance of paying attention to biophysical factors in the establishment of Msangu is also pointed out by Simuji et al. (2008b). They note that farmers seeking to establish Msangu face biophysical constraints, such as water constraints and poor soils, such that the survivability of the Msangu seedlings on small-scale farms is usually poor, ranging between $15 \%-60 \%$.

Apart from the challenges of integrating trees in the area, farmers also noted that they had challenges with the type of crop varieties that were distributed to them under the CA initiative. As part of the seed and fertilizer pack incentive (4 bags of $50 \mathrm{~kg}$ fertiliser bags and $10 \mathrm{~kg}$ of seed) for CA farmers, CA adopters received subsidized hybrid maize seeds. The crop varieties are high yielding and early maturing to counter the problem of a short rainy season. However, it appears that farmers have different experiences with the prescribed crop varieties. In the study, more than half of the respondents expressed disappointment with the quality of the crop varieties in the CA seed and fertilizer pack in CA. There are three main problems associated with hybrid maize varieties that farmers identified. These are the crops' susceptibility to pest attacks, the inability of the crop to withstand excess rains and the high fertilizer (nutrient) demand of the crop. Again, this scenario shows the importance of understanding local actors' livelihood circumstances in the deployment of any technology. According to the local elders, it is part of the local livelihood practice to store part of the crop harvest for a period longer than two farming seasons. This is meant to avert risks associated with various uncertainties, including climatic ones such as drought and crop failures due to lack of inputs, which farmers may face in the future. However, some hybrid maize varieties can only be stored for one season because of their susceptibility to pest attacks during storage. In this regard, some hybrid maize varieties prescribed to farmers sometimes increases farmers' vulnerability to these stresses and shocks.

\section{Conclusions}

The extension of conservation or environmental care to farming environments represents a shift in thinking of conservation as being exclusively a 'natural sites' conservation agenda to a new thinking that extends conservation to socio-ecological systems including agricultural systems. It attempts to break the divide between conservation and agriculture. As some scholars have pointed out, the divide between agriculture and conservation is detrimental to the advancement of both livelihoods and conservation (see also Fay \& Michon, 2005; Kereiva et al., 2007; Melania \& Sayid, 2011; Scherr \& McNeely, 2003). The piloting of agri-environmental management initiatives in places such as Zambia should thus be seen in the context of a strong push in much of the sustainable development literature for conservation solutions that posit a win-win solution for both livelihoods and conservation. In the protected area conservation approach, agricultural environments were never part of conservationist goals, as the thinking was that pristine environments and wild species were the most endangered and more in need of protection. Vaccaro and Beltran (2010), for example, argue that the protected area model almost always translates into the interdiction of local management and production systems and practices.

From an agricultural point of view, the emergency of agri-environmental management approaches such as conservation agriculture represents a change in agricultural practice, from an emphasis on technological advancement that encouraged the removal of wild tree species to one that now accommodates these species. An important aspect of this approach is that it has provided an opportunity for other actors, such as agricultural 
practitioners and farming households, who have traditionally been excluded from the 'nature' conservation agenda to participate in conservation efforts. Agri-environmental management is also instrumental in reinventing the image of agriculture in the eyes of conservationists. In this regard, the promotion of an agricultural approach that meets the multiple livelihood needs of farming households, as well as providing ecosystem services, allows us to view agriculture in a positive way as far as environmental conservation is concerned (Milestad et al., 2011).

This paper has pointed out that a range of agri-environmental approaches can be applied to extend conservation to agricultural environments. However, in the context of Zambia, conservation agriculture has emerged as the most popular approach and is being supported by a variety of actors, including non-governmental organisations, donor agencies and the state. While noting the merits of conservation agriculture as a sustainable land management approach, the paper also notes that there are several bottlenecks that limit its contribution to both livelihoods and environmental protection. In particular, it notes that the way agri-environmental approaches are framed and applied to a particular context is crucial for their success. In Chongwe, conservation agriculture is framed in such a way that what is deployed to the local setting is limited to a set of practices prescribed by implementing agencies. There is no focus on allowing a community-driven process where local farmers identify the best options for CA in their location (see also Dumanski et al., 2006). While there is so much emphasis on what farmers should do, there is little focus on what farmers have been doing or what farmers know in order to adapt CA properly to the local context. The study notes that the implementations of CA, and its capacity to deliver conservation dividends, are undermined by an emphasis on practices that are not in harmony with the organization of local livelihoods and the failure to take into account the biophysical conditions of the area.

The study also shows the importance of paying attention to the institutional arrangements governing access to natural resources in areas where conservation agriculture is being introduced. This is important, as most of the lessons being used in promotion of agro-environmental schemes in Zambia are primarily derived from the USA and some parts of South America, where these approaches have been relatively more advanced than in Africa (Buadron et al., 2007; WAC, 2010). Moreover, in these countries, we have to note that these practices are supported by payments for agri-environmental schemes and are taking place in a context where tenurial arrangements are different from most of rural Africa. It is essential that, as there is a focus on translating technology from one environment to another; practitioners avoid the flaws of past approaches where imported natural resources strategies simply ignored local institutional arrangements. The lessons derived from this paper are important, not only for Zambia but for many parts of Africa, as there are strong indications that this is the future trend in natural resource management as the discourse of sustainable development and its emphasis on ecosystem services continues to gain ground (see FAO, 2009; SADC/IUCN/SARDC, 2000).

\section{References}

Altieri, M. A., \& Nicholls, C. (2005). Agri-ecology and the Search for a Truly Sustainable Agriculture. UNEP: Mexico DF.

Amdur, L., Bertke, E., Freese, J., \& Marggraf, R. (2001). Agri-environmental Policy Measures in Israel: The Potential of Using Market Oriented Instruments. Environmental Management, 47, 859-875. http://dx.doi.org/10.1007/s00267-011-9655-y

Barker, A., \& Stockdale, A. (2008). Out of the Wilderness? Achieving Sustainable Development with Scottish National Parks. Journal of Environmental Management, 88(1), 181-193. http://dx.doi.org/10.1016/j.jenvman.2007.04.007

Batary, P., Bald, A., Kleijn, D., \& Tscharntke, T. (2011). Landscape-moderated Biodiversity Effects of Agri-environmental Management. Proc. Biol. Sci., 278, 1994-1902. http://dx.doi.org/10.1098/rspb.2010.1923

Baudron, F., Mwanza, H., Triomphe, B., \& Bwalya, M. (2007). Conservation Agriculture in Zambia: A Case Study of Southern Province. FAO/ACT: Nairobi, Kenya.

Bebbington, A. (1999). Capitals and Capabilities: A Framework for Analysing Peasant Viability, Rural Livelihoods and Poverty. World Development, 27(12), 2021-2044. http://dx.doi.org/10.1016/S0305-750X(99)00104-7

Benjamin, E. C. (2004). Livelihoods and Institutional Development in the Malian Sahel: A Political Economy of Decentralised Natural Resources Management. Unpublished PhD Dissertation, University of Michigan.

Borsotto, P., Henke R., Macri, M. C., \& Salvioni C. (2008). Participation in Rural Landscapes Conservation Schemes in Italy. Landscape Research, 33, 347-363. http://dx.doi.org/10.1080/01426390802046044 
Chambers, R., \& Conway, G. (1992). Sustainable rural livelihoods: practical concepts for the 21st century. Brighton, Institute of Development Studies.

Cunder, T. (2007). The Role of Rural Development Policy in Environmental and Land Management in Slovenia. Journal of Central European Agriculture, 8(2), 237-242.

Dumanski, J., Peiretti, R., Benets, J., McGarry, D., \& Pieri, C. (2006). The Paradigm of Conservation Agriculture. Proceedings of World Association of Soil and Water Conservation Paper No P1-7.

Dupuy, C. N., \& Dreyfus, B. L. (1992). Bradyrhizobium Populations Occur in Deep Soil under the Leguminous Tree Acacia albida. Applied Environmental Microbiology, 58(8), 2415- 2419.

Ellis, F. (2000). Rural Livelihoods and Diversity in Developing Countries. Oxford University Press: Oxford, 2000.

Fay, C., \& Michon, G. (2005). Redressing Forestry Hegemony When a Forestry Regulatory Framework is Best Replaced by an Agrarian One. Forests, Trees and livelihoods, 15, 193-209.

FAO. (2009). Scaling Up Conservation Agriculture in Africa. Strategies and Approaches. FAO: Addis Ababa.

Ferraro, P. J., \& Simpson, R. D. (2005). Protecting Forests and Biodiversity: Are Investments in Eco-Friendly Production Activities the Best Way to Protect Endangered Ecosystems and Enhance Rural Livelihoods? Forests, Trees and Livelihoods, 15, 167-181. http://dx.doi.org/10.1080/14728028.2005.9752518

Fisher, R., Seymour, S., \& Watkins, C. (2003). Conserving English Landscapes: Land Management and Agri-environmental Management. Environmental Management and planning A, 23, 19-41.

Gorman, M., Mannion, J., Kinsella, J., \& Bogue, P. (2001). Connecting Environmental Management and Farm Households Livelihoods: The Rural Environment Protection Scheme in Ireland. Journal of Environmental Policy and Planning, 3, 137-147. http://dx.doi.org/10.1002/jepp.76

Government of the Republic of Zambia (GRZ). (1998). Zambia Forest Action Plan. Challenges and Opportunities. GRZ: Lusaka, 1998.

Government of the Republic of Zambia (GRZ). (1999). The Zambia Forestry Act. GRZ: Lusaka.

Government of the Republic of Zambia (GRZ). (2007). National Environmental Policy. GRZ: Lusaka.

Kereiva, P., Watts, S., \& McDonald, R. (2007). Boucher T. Domesticated Nature: Shaping Landscapes and Ecosystems for Human welfare. Science, 316, 1866-1669. http://dx.doi.org/10.1126/science.1140170

Kleijn, D., \& Sutherland, W. J. (2003). How Effective are European Agri-environmental Schemes in Conserving and Promoting Biodiversity. Journal of Applied Ecology, 40, 947-967. http://dx.doi.org/10.1111/j.1365-2664.2003.00868.x

Mattison, H. A., \& Norris, K. (2005). Bridging the Gap between Agricultural Policy, Land Use and Biodiversity. Trends in Ecology and Evolution, 20(11), 610-616. http://dx.doi.org/10.1016/j.tree.2005.08.011

Melania, S., \& Sayid, S. (2011). Environmental Care in Agriculture. Journal of Agriculture and Environmental Ethics, 24(3), 243-246. http://dx.doi.org/10.1007/s10806-010-9255-5

Milestad, R., Ahstrom, J., \& Bjorklund, J. (2013). Essential Multiple Functions of Farms in Rural Communities and Landscapes. Renewable Agriculture and Food Systems, 26, 137-148. http://dx.doi.org/10.1017/S1742170510000529

Nyanga, P., Johnsen, F. H., \& Kalinda, T. H. (2012). Gendered Impacts of Conservation Agriculture and Paradox of Herbicide Use among Smallholder Farmers. International Journal of Technology and Development Studies, 3(1), 1-24.

Pretty, J. N., Morrison, J. I. L., \& Hine, R. E. (2003). Reducing Food Poverty by Increasing Agriculture Sustainability in Developing Countries. Agriculture Ecosystems and Environment, 95(1), 217-234. http://dx.doi.org/10.1016/S0167-8809(02)00087-7

Primak, R. B. (1993). Essentials of Conservation Biology. Sinauer Associates Inc, Sunderland, Massachusetts.

Prosperi, P., Terres, J. M., Doublet, S., \& Pointereau P. (2011). Conservation Agriculture Effects and Policy Support to Mitigate Soil Degradation in Midi-pyrenees (France). Land Degradation and Development, 22, 70-83. http://dx.doi.org/10.1002/ldr.1021

Reeves, R. (2011). Agriculture and the Environment, Where to Next? In Practice: Bulletin of the Institute of Ecology and Environmental Management, No 71, March, 2011.

Rigg, J. (2007). An Everyday Geography of the Global South. Routledge: London and New York. 
SADC; IUCN; SARDC. (2000). Biodiversity of Indigenous Forests and Woodlands in Southern Africa. SADC/IUCN, Maseru and Harare.

Scherr, S. J., \& McNeely, J. A. (2008). Biodiversity Conservation and agricultural sustainability: towards a new conservation paradigm of econ-agriculture landscapes. Philosophical Transactions of the Royal Society of Biological Sciences, 363, 477-494. http://dx.doi.org/10.1098/rstb.2007.2165

Scoones, I. (1998). Sustainable Rural Livelihoods: A Framework for Analysis. IDS Working Paper 72. Institute of Development Studies.

Simuji, S., Moono, D. S., \& Stevens, P. (2008a). Effects of Mature Falderbia Albida Tree on Productivity of Cereal and Legume Crops. In Golden Valley Research Trust, GART 2008 Year Book. Lusaka.

Simuji, S., Moono, D. S., \& Stevens, P. (2008b). Falderbia Albida (Msangu) Seedlings Survivability. In Golden Valley Agricultural Research Trust, GART 2008 Year Book. Golden Valley Research Trust: Lusaka.

The European Union (EU). (2005). Agri-environmental Measures and Rural Development: Over-view on General Principles, Types, Measures and Application. European Commission: Brussels, 2005.

The World Bank. (2008). Poverty and the Environment: Understanding Linkages at the Household Level. The World Bank: Washington DC.

Umar, B. B. (2012). Reversing Agro-based Land Degradation through Conservation Agriculture: Emerging Experience from Zambia's Smallholder Farming Sector. Sustainable Agriculture Research, 1(2), 72-87. http://dx.doi.org/10.5539/sar.v1n2p7

Vaccaro, I., \& Beltran, O. (2010). Conservationist Governmental Technologies in Western European Mountains: The Unfinished Transformations of the Pyrenees. Journal of Political Ecology, 17, 28-41.

Vandermeer, J., \& Perfecto, I. (2005). The Future of Conservation by R.E Green et al. Science, 308, 1257-1260. http://dx.doi.org/10.1126/science.308.5726.1257b

World Agro-forestry Center (WAC). (2010). Creating an Evergreen Agriculture in Africa. World Agro-Forestry Center: Nairobi.

Zwaan, P. (2010). Making Sense of EU State Aid Requirements: The Case of Green Services. Environment and Planning C: Government and Policy, 28, 768-782. http://dx.doi.org/10.1068/c08127j

\section{Copyrights}

Copyright for this article is retained by the author(s), with first publication rights granted to the journal.

This is an open-access article distributed under the terms and conditions of the Creative Commons Attribution license (http://creativecommons.org/licenses/by/3.0/). 